\section{第，1 表}

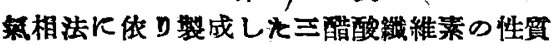

\begin{tabular}{|c|c|c|c|c|}
\hline & $\begin{array}{l}\text { 醋酸䧈 } \\
(\%)\end{array}$ & $\begin{array}{l}\text { 結合酼酸 } \\
\text { 量 }(\%)\end{array}$ & $\begin{array}{l}\text { 了七トン客 } \\
\text { 解庭 }(\%)\end{array}$ & $\begin{array}{l}\text { ク口的フォ } \\
\text { 厶溶解度 }(\%)\end{array}$ \\
\hline 1 & 62.3 & 0.01 & 9.2 & 透明可溶 \\
\hline 2 & 61.9 & 0.02 & 29.0 & II \\
\hline 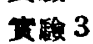 & 62.0 & 0.08 & 43.2 & " \\
\hline
\end{tabular}

第1表を見て注目すべき事は結合硫酸量の非常に小さいことで ある。通常の無水醋酸 一醌酸一硫酸浴に依る均一系醋化に於て醋 酸の量の多い程, 得られる醋酸繊維素の結合硫酸量の大きい事實 は吾人の屡々經驗する所であるが，本法に於て醋酸を全然使用し ない事か結合硫酸量の低下に與つて力があつたものと思はれる。

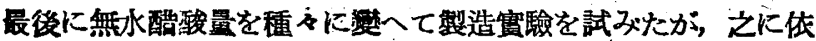

ると瀻維素 $10 \mathrm{~g}$ に對し，無水醌酸量 $19.8 \mathrm{~g}$ を使用してもなほ

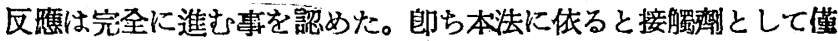
少の硫酸を用ひる以外は殆ど理諭量の無水醌酸のみで纖踓素の醌

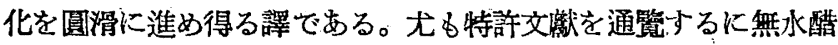
酸の沸點近くでその蒸氣に依り纖維素の醌化を行ふ試みが散見さ れるが(例へば Societe Chim. des Usines dn Rhone; 獨特許 258,879 ; 英特許 25,893 等)。著者等の經驗に依ると醋化溫度を $45^{\circ} \mathrm{C}$ に高めても既に製品の崩整は著しく起つたから，上の如き 高溫度は恐らく惯用には供炕られいであら5。

䏌該方法を利用寸ると，織維素製品例へば人絹，セロフォン，

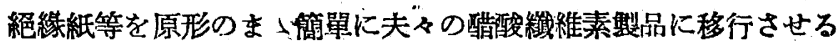
事が出來る譯で工業上興味梁いと思はれる。

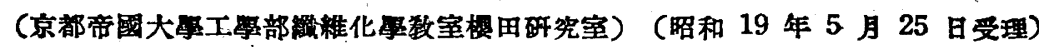

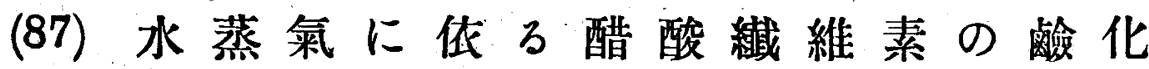

谷口政 勝・細 野 正夫

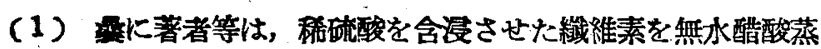
氣で飽和せる容器內に放置することに位り嘰維素の氣相系醋化を 行つたが (谷口・細野, 本誌, 昭和 $20,49 ， 91$ ) これと全く同

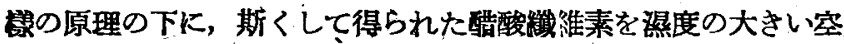
氣中に放置することに依り夫の殮化を試みた。この場合，醌酸瀻 維素內には最初含浸さ中た挽酸力牫留して居るから之が今度は氣

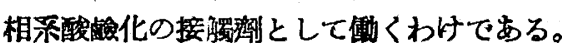

宫驗例の一を揭げると第1蒜の如くである。

\section{第 1 表}

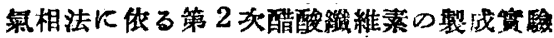

温度 $25^{\circ} \mathrm{C}$, 愒對添度 $150 \%$, 反應容器の容量 $20 \mathrm{l} / 10 \mathrm{~g}$ 試料

\begin{tabular}{|c|c|c|c|}
\hline $\begin{array}{c}\text { 战化時間 } \\
\text { 日 }\end{array}$ & $\begin{array}{c}\text { 醋酸價 } \\
\%\end{array}$ & 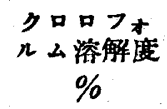 & $\begin{array}{c}\text { アセトン } \\
\text { 溶解度 } \\
\% \%\end{array}$ \\
\hline 0 & 59.7 . & 100 & 61.2 \\
\hline 1 & $58.8^{\bullet}$ & 100 & 85.5 \\
\hline 2 & 57.8 & 99.3 & 96.2 \\
\hline 3 & 56.7 & 71.5 & 92.3 \\
\hline 6 & 53.9 & 43.3 & 45.7 \\
\hline
\end{tabular}

第 1 表を見るに铪化反礁は圆滑に進行し，畧化物のナセトン溶

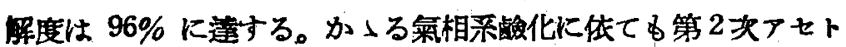

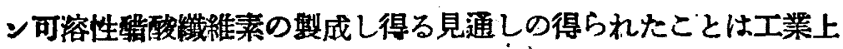
與味染いと思はれる。

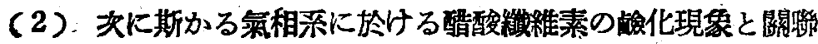
して思ひつくことは; 醋酸轿倠素の咛藏中に於けるる化學分解の問

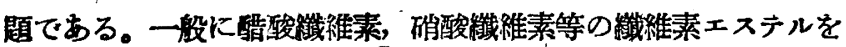
空氣中で長期間貯へておくと度々酸臭を發し，時に不都合な性賀 の登化を率らすことを吾人はよく經驗する。これに就き著者等の

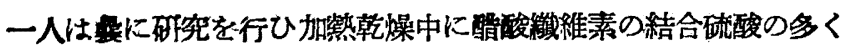
が遊離硫酸に移行する事惯を認めた（谷口，本誌，昭和 16,44 ， 953)。郎ち乾燥せる醌酸瀻維素，特に第 1 次醋酸絟維素中には多 かれ少かれ殆ど不可避的に遊雄碳酸力存在して居ると考へられる

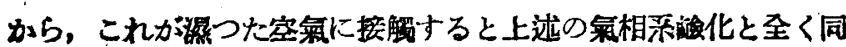

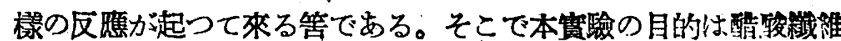
素の唄藏中に於ける分解現象を一種の氣相系的會化反䧹として取扱 ひ，種々の惯驗條件の下に該反鷹が如何に進行するかを检へるる ある。試料としては故意に結合硫酸を多く含む第 1 次醋酸纎維素 をつくり，これを種くの㴓度及び濕度の空氣中に放置して畧化の 進行狀態を調べた。その結果を第 2 及び 3 表に示す。

$$
\text { 第 } 2 \text { 表 }
$$

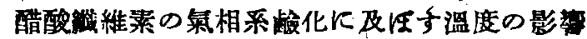
相對缶度 $100 \%$ ，原試料の全硫酸量 $9.6 \%$

時間酷酸 䚇 \%

\begin{tabular}{rrrr} 
& $25^{\circ} \mathrm{C}$ & $47^{\circ} \mathrm{C}$ & $70^{\circ} \mathrm{C}$ \\
\hline 0 & 45.9 & 45.9 & 45.9 \\
2 & 44.9 & 40.8 & 17.1 \\
5 & 43.4 & 32.6 & 4.7 \\
10 & 40.1 & 20.2 & 1.5
\end{tabular}

第 3 表

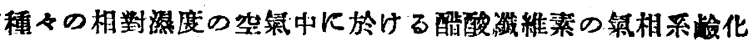
溫度 $25^{\circ} \mathrm{C}$, 原試料の全硫酸量, $.0 \%$ 、

酷 酸 摆 $\%$

\begin{tabular}{ccccc} 
日数/相濧溹度 & $0 \%$ & $65 \%$ & $100 \%$ & 水漬 \\
\hline 0 & 51.6 & 51.6 & 51.6 & 51.6 \\
2 & 50.3 & 43.4 & 39.6 & - \\
5 & 48.5 & 34.6 & 27.8 & 48.5 \\
10 & 49.0 & 21.9 & 15.5 & 47.3
\end{tabular}

先づ第 2 表を見るに俭化に及ぼす溫度の影響は特に著しい。例 へば $70^{\circ} \mathrm{C}$ に於ては僅々 10 時間の間に酛酸偠は $46 \%$ から $1.5 \%$ に淢少する。次第 3 表を見るに濕度の高い程當然裣化はよく進 む。佮相對濕度 0\%. でも初期に於て多少畧化の起るのは不可避 的に試料中に微量残存せし水分の影響と思はれる。これ等に對し

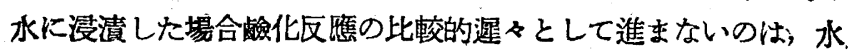
に依り遊離硫酸分か汼釋された雼であら5。

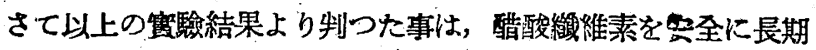
間保存する㼻には可及的低溫に於て充分乾燥した空氣中に於て之 をなすへきこと，若しこれが困難なれば䕗ろ水に浸漬して䝪へる とよいと砉ふ事である。 